\title{
MUTASI PEJABAT FUNGSIONAL KE DALAM JABATAN STRUKTURAL DI ERA OTONOMI DAERAH
}

\author{
Nelson Bastian Nope \\ Ilmu Hukum Program Pascasarjana \\ Univeristas Nusa Cendana Kupang \\ E-mail : nopenelson@gmail.com
}

\begin{abstract}
Mutation arrangement of functional official to occupy structural position did not arrange specifically in legal authority, but by applying law no 5 years 2014 about apparatus civil of country so in region refer to article 68 paragraph 4 that goverment employee can move inter and between high leadership position, administration position, and functional position in central institute and regional based on qualification, competency, and job scorring. Research result shown that arrangememnt, procedure, and mekanism of mutation to funtional official to occupy structural position which done in region is by corporation of position judgment and promotion that has duty to give judgment to region head but didn't give full care of qualification, competency, and assessment of goverment employee's job so didn't create the principle of appointment.
\end{abstract}

Key words : Arrangement, mutation, functional,structural position

\begin{abstract}
Abstrak
Pengaturan mutasi pejabat fungsional untuk menduduki jabatan struktural belum diatur secara khusus dalam ketentuan perundang-undangan, namun dengan berlakunya Undang-undang Nomor 5 Tahun 2014 tentang Aparatur Sipil Negara, maka di daerah mengacu pada Pasal 68 ayat ( 4 ) bahwa PNS dapat berpindah antar dan antara Jabatan Pimpinan Tinggi, Jabatan Administrasi, dan Jabatan Fungsional di Instansi Pusat dan Daerah berdasarkan kualifikasi, kompetensi, dan penilaian kinerja. Hasil penelitian menunjukan bahwa prosedur dan mekanisme mutasi pejabat fungsional untuk menduduki jabatan struktural yang dilakukan di daerah adalah melalui Badan Pertimbangan Jabatan dan Kepangkatan atau Baperjakat yang tugasnya memberikan pertimbangan kepada Kepala daerah namun tidak sepenuhnya memperhatikan kulifikasi, kompetensi dan penilaian kinerja Pegawai Negeri Sipil sehingga belum terciptanya asas penempatan.
\end{abstract}

Kata Kunci : Pengaturan, Mutasi, Jabatan Fungsional, Struktural.

\section{A. Pendahuluan}

Di era reformasi ini untuk mewujudkan sistem pemerintahan yang demokratis, bersih, dan berwibawa telah menjadi prioritas utama bagi rakyat dan pemerintahan Indonesia. Salah satu upaya reformasi itu adalah penataan aparatur pemerintah (Sri Hartini, 2010 : 5). Oleh karena itu, untuk menyempurnakan 
reformasi birokrasi yang dikehendaki, maka selain adanya perubahan konsep dalam struktur pemerintahan, juga perlu dilakukan upaya untuk menempatkan orang-orang atau aparatur yang tepat dalam mengisi jabatan dalam struktur pemerintahan (the right man on the right position) The right man on the right position merupakan istilah yang berasal dari adagium The right on the right place yang bermakna penempatan orang yang tepat pada tempat atau posisi yang tepat pula.

Jabatan dalam pemerintahan daerah pada hakikatnya terbagi atas jabatan fungsional dan jabatan struktural. Ketika jabatan fungsional menekankan pada tataran jenjang karier atau fungsional kepegawaian, maka jabatan struktural menunjukkan pada kedudukan, tugas, tanggung jawab, wewenang, dan hak seorang PNS dalam rangka memimpin suatu satuan organisasi.

Pengangkatan PNS dalam jabatan struktural telah diatur dalam Peraturan Pemerintah No. 13 Tahun 2002 tentang Perubahan Pertama Peraturan Pemerintah No. 100 Tahun 2000 Tentang Pengangkatan Pegawai Negeri Sipil Dalam Jabatan Struktural. Sebenarnya peraturan ini tidak menetapkan ketentuan baku dalam mengatur tentang mekanisme dan prosedur pengangkatan PNS dalam jabatan struktural melainkan hanya sebatas persyaratan. Oleh karena itu tidak heran jika di masyarakat, proses pengangkatan PNS dalam jabatan sering dikaitkan dengan praktik korupsi, kolusi, nepotisme, money politic, sistem yang tertutup, balas jasa, atau pun kedekatan politik dengan penguasa.

Guna menjawab problematika ketidakteraturan mengenai pengangkatan PNS untuk menempati jabatan struktural tersebut, pemerintah berusaha menjabarkan pengaturannya melalui Surat Edaran Kementerian Pendayagunaan Aparatur Negara dan Reformasi Birokrasi (KEMENPANRB) No. 16 Tahun 2012 Tentang Tata Cara Pengisian Jabatan Struktural yang Lowong di Instansi Pemerintah. Peraturan tersebut mengamanatkan bahwa pengangkatan jabatan struktural dapat dilakukan secara terbuka dengan syarat berdasarkan peraturan pemerintah. Namun masih mengisahkan persoalan khusus mengenai pengisian jabatan atau mutasi PNS dari jabatan fungsional ke jabatan struktural. Pengisian jabatan struktural dari jabatan fungsional sering terjadi di daerah sementara daerah masih 
kekurangan tenaga fungsional sehingga perlu adanya suatu petunjuk yang jelas tentang kedudukan pejabat fungsional dalam menempati jabatan struktural. Tulisan ini mengkaji beberapa permasalahan terkait pengaturan mutasi pejabat fungsional untuk menduduki jabatan struktural di era otonomi daerah serta prosedur dan mekanisme mutasi pejabat fungsional untuk menduduki jabatan struktural telah memenuhi prinsip penempatan.

\section{B. Metode Penelitian}

Tipe penelitian yang digunakan adalah penelitian yuridis normatif yakni penelitian yang difokuskan untuk mengkaji penerapan asas-asas, kaidah-kaidah atau norma-norma dalam hukum positif, terutama berkaitan dengan peraturan perundang-undangan yang berlaku secara nasional maupun secara regional. Dalam menganalisis berbagai informasi atau bahan hukum yang diperoleh, maka metode pendekatan yang digunakan adalah pendekatan perundang-undangan (statute approach), pendekatan konsep (conceptual approach) dan pendekatan sistem hukum atau proses hukum (systematical approach). Pendekatan tersebut merupakan penelitian untuk melakukan pengkajian terhadap Peraturan perundangundangan yang mengatur tentang mutasi pejabat fungsional ke dalam jabatan struktural. Untuk memperoleh bahan dan informasi yang dibutuhkan dalam penelitian ini, maka penelitian dilakukan di Perpustakaan Daerah Provinsi Nusa Tenggara Timur dan Perpustakaan Pascasarjana Universitas Nusa Cendana Kupang.

\section{Hasil Penelitian dan Pembahasan}

\section{Konsep Jabatan}

Secara etimologi, kata jabatan berasal dari kata dasar "jabate yang ditambah imbuhan -an, yang berdasarkan Kamus Besar Bahasa Indonesia diartikan sebagai “pekerjaan (tugas) dalam pemerintahan atau organisasi yang berkenaan dengan pangkat dan kedudukan”(Poerwasunata, 2003 : 67). Sedangkan menurut Logeman dalam bukunya yang diterjemahkan oleh Makkatutu dan Pangkerego, jabatan adalah: " Lingkungan kerja awet dan digaris batasi, dan yang disediakan untuk ditempati oleh pemangku jabatan yang ditunjuk dan disediakan untuk diwakili oleh mereka sebagai pribadi 
(Makkatutu dan Pangkerego, 1948 : 124). Logemann menunjukkan pentingnya perhubungan antara negara sebagai organisasi dengan pengisian jabatan, oleh karena itu teorinya disebut Teori Jabatan (Pudja Pramana KA, 2009 : 285).

Jabatan struktural adalah Kedudukan yang menunjukkan tugas, tanggung jawab, wewenang dan hak seorang PNS dalam rangka memimpin suatu satuan organisasi negara sedangkan Jabatan Fungsional adalah Kedudukan yang menunjukkan tugas, tanggung jawab, wewenang dan hak seseorang PNS dalam suatu organisasi yang dalam pelaksanaan tugasnya didasarkan pada keahlian dan/atau ketrampilan tertentu serta bersifat mandiri (Sri Hartini, 2010 : 149).

Jabatan fungsional pada hakikatnya adalah jabatan teknis yang tidak tercantum dalam struktur organisasi, namun sangat diperlukan dalam tugastugas pokok dalam organisasi Pemerintah. Jabatan fungsional Pegawai Negeri Sipil terdiri atas jabatan fungsional keahlian dan jabatan fungsional keterampilan. Jabatan fungsional keahlian adalah kedudukan yang menunjukkan tugas yang dilandasi oleh pengetahuan, metodologi dan teknis analisis yang didasarkan atas disiplin ilmu yang bersangkutan dan/atau berdasarkan sertifikasi yang setara dengan keahlian dan ditetapkan berdasarkan akreditasi tertentu. Sedangkan jabatan fungsional ketrampilan adalah kedudukan yang menunjukkan tugas yang mempergunakan prosedur dan teknik kerja tertentu serta dilandasi kewenangan penanganan berdasarkan sertifikasi yang ditentukan.

Menurut A.W. Widjaja prinsip penempatan adalah the right man on the right place (penempatan orang yang tepat pada tempat yang tepat). Untuk dapat melaksanakan prinsip ini dengan baik, ada dua hal yang perlu diperhatikan (Sri Hartini, 2010 : 97), yaitu :

1. Adanya analisis tugas jabatan (job analisys) yang baik. Suatu analisis yang menggambarkan tentang ruang lingkup dan sifat-sifat tugas yang dilaksanakan sesuatu unit organisasi dan syarat-syarat yang harus dimiliki oleh pejabat yang akan menduduki jabatan di dalam unit organisasi itu.

2. Adanya Penilaian Pelaksanaan Pekerjaan (kecakapan pegawai) dari masingmasing pegawai yang terpelihara dengan baik dan terus-menerus. Dengan adanya penilaian pekerjaan ini dapat diketahui tentang sifat, kecakapan, disiplin, prestasi kerja, dan lain-lain dari masing-masing pegawai. 


\section{Konsep Mutasi}

Menurut Alex S. Nitisemito pengertian mutasi adalah kegiatan dari pimpinan perusahaan untuk memindahkan karyawan dari suatu pekerjaan ke pekerjaan lain yang dianggap setingkat atau sejajar (Alex. S. Nitisemito, 1996 :132). Selanjutnya H. Malayu S. P. Hasibuan menyatakan bahwa mutasi adalah suatu perubahan posisi/ jabatan/ tempat/ pekerjaan yang dilakukan baik secara horizontal maupun vertikal di dalam satu organisai. Pada dasarnya mutasi termasuk dalam fungsi pengembangan karyawan, karena tujuannya untuk meningkatkan efisiensi dan efektivitas kerja dalam perusahaan (pemerintahan) tersebut (SP. M. Hasibuan, 1994 :102).

Jadi, dapat disimpulkan bahwa mutasi diartikan sebagai perubahan mengenai atau pemindahan kerja/ jabatan lain dengan harapan pada jabatan baru itu dia akan lebih berkembang. Sedangkan landasan hukum pelaksanaan mutasi, pengangkatan dan pemberhentian pegawai negeri sipil adalah pertama, Peraturan Pemerintah Nomor 43 Tahun 1999, tentang Pokok-Pokok Kepegawaian (Lembaga Negara Tahun 1999 Nomor 16 Tambahan lembaran Negara Nomor 3890), dan kedua, Tentang wewenang pengangkatan, pemindahan, pemberhentian pegawai negeri sipil, diatur dalam Peraturan Pemerintah Nomor 96, Tahun 2000. Kedua peraturan perundang-undangan tersebut di atas merupakan pedoman pelaksanaan mutasi kepegawaian di setiap instansi pemerintah umum dan daerah.

Menurut Simamora manfaat pelaksanaan mutasi adalah (a) memenuhi kebutuhan tenaga kerja di bagian atau unit yang kekurangan tenaga kerja tanpa merekrut dari luar; (b) memenuhi keinginan pegawai sesuai dengan pekerjaan; (c) memberikan jaminan bagi pegawai bahwa dia tidak akan diberhentikan; (d) tidak terjadi kejenuhan; dan (e) motivasi dan kepuasan kerja yang lebih tinggi, berkat tantangan dan situasi baru yang dihadapi (Bilson Simamora, 2005 : 66).

Mutasi juga dapat menurunkan kegairahan kerja karena dianggap sebagai hukuman dan memperburuk produktivitas kerja karena adanya ketidaksesuaian dan ketidakmampuan kerja karyawan. Bila terjadi keadaan yang demikian 
maka mutasi tidak mencapai tujuan yang diharapkan, yaitu bertambahnya efektivitas dan efesiensi dalam perkerjaan. Menurut Nitisemito, hal ini terjadi karena: (a) Karyawan tersebut telah terlanjur mencintai perkerjaanya; (b) Hubungan kerjasama yang baik dengan sesama rekan; dan (c) Perasaan dari karyawan bahwa pekerjaan-pekerjaan lain yang sederajat, dan lain-lain (Nitisemito, Alex S. 2002, :119).

Sedangkan tujuan pelaksanaan mutasi menurut H. Malayu S.P Hasibuan antara lain, adalah:

a. Untuk meningkatkan produktivitas kerja pegawai.

b. Untuk menciptakan keseimbangan antara tenaga kerja dengan komposisi pekerjaan atau jabatan.

c. Untuk memperluas atau menambah pengetahuan pegawai.

d. Untuk menghilangkan rasa bosan/ jemu terhadap pekerjaannya.

e. Untuk memberikan perangsang agar karyawan mau berupaya meningkatkan karier yang lebih tinggi.

f. Untuk menyesuaikan pekerjaan dengan kondisi fisik pegawai.

g. Untuk mengatasi perselisihan antara sesama pegawai.

h. Untuk mengusahakan pelaksanaan prinsip orang tepat pada tempat yang tepat (H. Malayu S.P Hasibuan, 2003 : 102).

Selain itu tujuan mutasi yang terkandung dalam Peraturan Pemerintah Nomor 43 Tahun 1999, tentang Pokok-Pokok Kepegawaian adalah (a) Peningkatan produktivitas kerja; (b) Pendayagunaan pegawai; (c) Pengembangan karier; (d) Penambahan tenaga-tenaga ahli pada unit-unit yang membutuhkan; (e) Pengisian jabatan-jabatan lowongan yang belum terisi; dan (f) Sebagai hukuman.

\section{Pengaturan Mutasi Pejabat Fungsional untuk Menduduki Jabatan Struktural di Era Otonomi Daerah.}

Berdasarkan pada hasil temuan penelitian ditemukan bahwa pengaturan tentang mutasi PNS telah diatur dalam ketentuan Undang-Undang Nomor 5 Tahun 2014 tentang Aparatur Sipil Negara, Undang Undang Nomor 23 Tahun 2014 tentang Pemerintahan Daerah, dan Peraturan Pemerintah Nomor 9 Tahun 
2003 tentang Wewenang Pengangkatan, Pemindahan dan Pemberhentian Pegawai Negeri Sipil, serta Keputusan Kepala Badan Kepegawaian Negara Nomor 13 tahun 2003 tentang Petunjuk Teknis Pelaksanaan Peraturan Pemerintah Nomor 9 Tahun 2003 tentang Wewenang Pengangkatan Pemindahan, dan Pemberhentian Pegawai Negeri Sipil.

Selanjutnya sesuai dengan ketentuan Pasal 73 ayat 1 Undang-Undang Nomor 5 Tahun 2014 tentang Aparatur Sipil Negara mengatur bahwa "Setiap PNS dapat dimutasi tugas dan/atau lokasi dalam 1 (satu) Instansi Pusat, antar Instansi Pusat, 1 (satu) Instansi Daerah, antar Instansi Daerah, antar Instansi Pusat dan Instansi Daerah, dan ke perwakilan Negara Kesatuan Republik Indonesia di luar negeri”. Ayat 4 Pasal 68 "PNS dapat berpindah antar dan antara Jabatan Pimpinan Tinggi, Jabatan Administrasi, dan Jabatan Fungsional di Instansi Pusat dan Daerah berdasarkan kualifikasi, kompetensi, dan penilaian kinerja

Menurut Pasal 1 angka (3) Undang-undang Nomor 5 Tahun 2014 pegawai negeri Sipil adalah warga negara Indonesia yang memenuhi syarat tertentu, diangkat sebagai Pegawai ASN secara tetap oleh pejabat pembina kepegawaian untuk menduduki jabatan pemerintahan. Istilah mutasi sendiri atau yang dalam beberapa literatur disebut pemindahan dalam pengertian sempit dapat dirumuskan sebagai suatu perubahan dari suatu jabatan dalam suatu klas ke suatu jabatan dalam klas yang lain yang tingkatannya tidak lebih tinggi atau lebih rendah (yang tingkatnya sama) dalam rencana gaji (Moekijat, 1989 : 107). Dalam pengertian yang lebih luas konsep mutasi dirumuskan sebagai suatu perubahan posisi/jabatan/tempat/ pekerjaan yang dilakukan baik secara horizontal maupun vertikal (promosi/demosi) di dalam suatu organisasi (Haibuan, 1994 : 114), sehingga pada dasarnya mutasi dalam pengertian perubahan horisontal hanyalah merupakan salah satu bagian dari pengertian mutasi itu sendiri.

Jabatan struktural menurut Pasal 1 angka (10) Peraturan Pemerintah Nomor 9 Tahun 2003 adalah suatu kedudukan yang menunjukkan tugas, tanggung jawab, wewenang, dan hak seseorang Pegawai Negeri Sipil dalam 
rangka memimpin suatu satuan organisasi Negara. Dalam Undang-undang Nomor 5 Tahun 2014 jabatan struktural dikenal dengan istilah jabatan pimpinan tinggi.

Syarat-syarat bagi Pegawai Negeri Sipil (PNS) yang akan dimutasikan dalam jabatan struktural adalah minimal mencukupi pangkat atau satu tingkat di bawah pangkat terendah dari jabatan struktural serta disesuaikan dengan prestasi kinerja. PNS yang telah memiliki pangkat satu tingkat lebih rendah dari jenjang pangkat untuk jabatan struktural tertentu, dipandang telah mempunyai pengalaman dan kemampuan yang dibutuhkan untuk melaksanakan jabatannya. Sedangkan pihak yang berwenang untuk menentukan syahnya persyaratan mutasi jabatan struktural adalah Badan Pertimbangan Jabatan dan Kepangkatan (Baperjakat) Kabupaten/Kota yang ditetapkan oleh pejabat pembina kepegawaian daerah Kabupaten/Kota setelah mendapat pertimbangan dari Baperjakat Kabupaten/Kota. Persyaratan mutasi pejabat struktural harus mengacu kepada Peraturan Pemerintahan Nomor 100 Tahun 2000 juncto Peraturan Pemerintah Nomor 13 Tahun 2002 tentang Pengangkatan Pegawai Negeri Sipil Dalam Jabatan Struktural.

Berdasarkan pada penjelasan di atas dapat dikemukakan bahwa seorang PNS yang akan menduduki jabatan struktural harus memenuhi persyaratan tertentu, termasuk senioritas. Senioritas merupakan salah satu syarat atau kriteria dalam mutasi jabatan. Namun senioritas di sini tidak dimaknai hanya lamanya masa kerja seorang pegawai, namun juga senioritas dalam pengetahuan, pengalaman kerja dan kepangkatan sehingga memiliki spesialisasi pekerjaan. Pegawai yang senior dianggap lebih memiliki pengalaman dan keterampilan karena masa kerjanya lebih lama. Namun apabila dilihat dari persyaratan yang lain seperti tingkat pendidikan belum memenuhi syarat minimal S1 maka PNS yang bersangkutan tidak bisa dimutasikan ke jabatan struktural. Dan sebaliknya meskipun pengalaman kerja baru 8 (delapan) tahun, namun sudah menduduki jabatan satu tingkat di bawahnya serta memiliki pendidikan minimal S1, maka PNS yang lebih muda yang berhak untuk dimutasikan ke jabatan struktural. 
Berdasarkan uraian diatas, apabila terjadi maka PNS yang akan dimutasi ke jabatan struktural yang bisa saja tidak sesuai dengan kualifikasi pendidikan. Sehingga PNS yang bersangkutan berlatar pendidikan sarjana dan spesialisasi, namun dapat saja memperoleh yang tentu tidak sesuai dengan kompetensi yang harus dimiliki oleh calon pejabat struktural yang seharusnya berlatar belakang di bidang yang mestinya didukuinya. Sementara, untuk mendapatkan pejabat yang mempunyai kompetensi yang tinggi maka ketika akan dimutasikan harus sesuai antara tingkat pendidikan dengan lowongan formasi jabatan yang akan diisi dengan mempertimbangkan aspek kompetensi dan pendidikan sehingga diharapkan PNS yang bersangkutan lebih cakap, kreatif, inovatif dalam menyelesaikan tugas-tugasnya pada jabatan tersebut dengan baik. Oleh karena itu, minimal harus dapat menyelesaikan tugasnya dengan mandiri dalam menyelesaikan pekerjaanya dengan baik, tanpa harus mendapatkan bimbingan dari atasanya secara terus menerus. PNS yang dimutasikan dan ditempatkan sesuai dengan jenjang pendidikan dan keterampilan yang dimilikinya cenderung akan menunjukkan prestasi kerja dibandingkan dengan PNS yang didudukkan pada suatu jabatan namun tidak sesuai dengan tingkat pendidikannya.

Proses mutasi pejabat, intervensi penguasa jelas ada, karena nilai-nilai primordial, kesukuan maupun keagamaan masih menjadi bahan pertimbangan dalam penentuan pejabat struktural. Selain itu, yang tidak kalah pentingnya dalam penentuan mutasi pejabat adalah nilai kedekatan dan kekerabatan. Kondisi ini jelas akan mengurangi kesempatan bagi pegawai yang memiliki kompetensi dan kualitas untuk meningkatkan karir dan prestasi kerja. Disamping itu, keadaan ini juga akan menempatkan pegawai bukan pada tempat yang tepat karena hanya berdasarkan kepentingan individu penguasa.

Nilai intervensi memang diperlukan dalam rangka menata dan menempatkan pegawai pada tempat dan pekerjaan yang tepat. Namun apabila intervensi dimaksudkan untuk memasukkan pegawai yang kurang memiliki kompetensi karena melihat aspek kedekatan, maka akan berdampak pada diri individu pegawai dan pelaksanaan tugas dan fungsi jabatan. Dalam diri 
pegawai dampak yang nyata adalah pegawai yang dimutasi ke jabatan struktural karena aspek kedekatan dan kekerabatan cenderung kurang dapat mengembangkan diri sehingga kurang berprestasi. Sedangkan dari aspek pelaksanaan tugas dan fungsi jabatan juga akan kurang maksimal karena pegawai yang ditempatkan tidak sesuai dengan kompetensi jabatan yang didudukinya.

Makna intervensi tidak selalu negatif. Intervensi juga bermakna campur tangan pimpinan dalam penempatan pegawai yang sesuai dengan bidangnya merupakan bentuk intervensi positif. Dengan adanya intervensi positif maka akan ditempatkan pegawai yang sesuai dengan job spesification dari jabatan yang akan diembannya. Oleh sebab itu, seharusnya pimpinan yang mengetahui potensi dan kemampuan bawahannya harus melakukan intervensi positif dalam rangka menempatkan pegawai pada tempat dan pekerjaan yang tepat sehingga pegawai dapat bekerja secara maksimal dan profesional.

Intervensi yang dilakukan oleh kepala daerah (Gubernur/Bupati/walikota) sebenarnya bukan dikategorikan sebagai bentuk intervensi. Namun sebagai bentuk kewenangan yang dimiliki oleh Gubernur/Bupati/walikota sebagai Kepala Daerah untuk menunjuk dan menetapkan pejabat struktural di lingkungan daerah provinsi/Kabupaten/Kota. Memang perlu diakui bahwa mutasi pejabat tidak lepas dari kepentingan gubernur/Bupati/Walikota secara profesional dan politis. Secara profesional, gubernur/Bupati/Walikota menginginkan pejabat struktural yang ditunjuk dapat melaksanakan visi dan misinya dalam rangka menyukseskan program kerja pemerintah daerah. Sedangkan dari aspek politis, penempatan pejabat struktural cenderung diisi oleh pegawai yang memiliki kedekatan dan bentuk balas budi terhadap seorang Gubernur/Bupati/Walikota sebagai tim suksesnya.

\section{Prosedur dan Mekanisme Mutasi Pejabat Fungsional Untuk Menduduki}

\section{Jabatan Struktural.}

Sesuai dengan hasil temuan penelitian ditemukan bahwa Prosedur dalam pengangkatan dan pemindahan jabatan struktural aparatur pemerintah daerah yang dilakukan oleh Kepalah Daerah adalah dengan membentuk Badan 
Pertimbangan Jabatan dan Kepangkatan atau Baperjakat yang tugasnya memberikan pertimbangan kepada Gubernur/Bupati/Walikota dalam pengangkatan dan pemindahan jabatan struktural. Tiap jabatan adalah suatu lingkungan pekerjaan tetap yang dihubungkan dengan organisasi sosial tertinggi, yang diberi nama negara. Jabatan yang dimaksud ialah suatu jabatan negara (Utrecht, 1960 : 138).

Tentunya prosedur pengangkatan dan pemindahan jabatan struktural tidak terlepas dari asas umum prosedur. Asas umum prosedur bertumpu pada tiga landasan utama hukum administrasi yaitu, Pertama, asas negara hukum, kedua, asas demokrasi, ketiga asas instrumental (Philipus M. Hadjon, 1994 : 9). Asas negara hukum dalam prosedur utamanya berkaitan dengan perlindungan hakhak dasar.

Asas demokrasi dalam prosedur berkenaan asas keterbukaan, dalam penyelenggaraan pemerintahan. Asas keterbukaan mewajibkan pemerintah untuk secara aktif memberikan informasi kepada masyarakat tentang suatu permohonan atau suatu rencana tindak pemerintahan dan mewajibkan untuk memberikan penjelasan kepada masyarkat atas hal yang diminta. Keterbukaan pemerintahan memungkinkan peran serta masyarakat dalam pengambilan keputusan. Di samping itu asas keterbukaan mewajibkan pemerintah untuk mengumumkan setiap keputusan pemerintah.

Asas instrumental meliputi asas efisiensi (doelmatigheid : daya guna) asas efektivitas (doeltreffenheid : hasil guna). Dewasa ini mungkin masih banyak prosedur di bidang pemerintahan kita yang masih belum berdaya guna dan berhasil guna. Dalam hubungan itu deregulasi dibidang pemerintahan khususnya menyangkut prosedur pemerintahan masih sangat dibutuhkan.

Tujuan dibentuk Badan Pertibamangan Jabatan dan Kepangkatan sesuai Pasal 14 ayat (1) Peraturan Pemerintah No.100 Tahun 2000 tentang pengkatan Pegawai Negeri Sipil dalam jabatan satruktural bahwa untuk menjamin kualitas dan obyektifitas dalam pengangkatan dan pemberhentian Pegawai Negeri Sipil dalam dan dari jabatan struktural Eselon II ke bawah di setiap instansi. 
Proses pengembangan karier dalam jabatan struktural pada setiap tingkat jabatan pimpinan dilakukan analisis jabatan untuk diperoleh ukuran tugas dan spesifikasi jabatan. Dalam Pasal 5 Peraturan Pemerintah No. 100 Tahun 2000 tentang pengangkatan Pegawai Negeri Sipil dalam Jabatan struktural ditentukan persyaratan untuk dapat diangkat dalam jabatan struktural adalah :

a. Berstatus Pegawai Negeri Sipil.

b. Serendah-rendahnya menduduki pangkat 1 (satu) tingkat dibawah jenjang pangkat yang ditentukan.

c. Memiliki kualifikasi dan tingkat pendidikan yang ditentukan.

d. Semua unsur penilaian parestasi kerja sekurang kurangnya bernilai baik dalam 2 (dua) tahun terakhir.

e. Memiliki kompetentis jabatan yang diperlukan.

f. Sehat Jasmani dan Rohani.

Jabatan yang telah dianalisi kemudian dilakukan evaluasi dengan memperbandingkan bobot tanggungjawab dan job faktor yang dipergunakan sebagai bahan perbandingan. Hal tersebut dapat dipakai sebagai gambaran tentang jabatan yang dipergunakan sebagai tangga karier. Hal ini agar dapat terjadi jabatan yang setingkat eselonnya berbeda bobotnya, sehingga pengembangan karier tidak selalu berarti perpindahan kearah vertikal tetapi dapat pula kearah horizontal.

Stratifikasi pemangku jabatan dilakukan analisis terhadap seluruh eselon jabatan sehingga dapat direncanakan perpindahan wilayah kerja. Perpindahan jabatan disesuaikan dengan jenis keahlian pemangku jabatan agar dapat dihindari penempatan seseorang yang tidak tepat. Adapun pendidikan dan pelatihan dalam memangku jabatan struktural wajib diikuti di samping memperhatikan faktor senioritas dalam kepangkatan, usia dan pelatihan jabatan, serta pengalaman yang dimiliki.

Eselon dan jenjang jabatan struktural tidak terlepas dari pendidikan dan pelatihan untuk memberikan ilmu pengetahuan dan ketrampilan sebelum seseorang mendapat kepercayaan dalam memangku jabatan. Jenis pendidikan dan pelatihan juga dimaksudkan untuk memenuhi persyaratan kemampuan 
minimal yang ditetapkan oleh suatu jabatan. Jenis pendidikan dan pelatihan dapat diketahui melalui analisis jabatan pada setiap jabatan, dimana hasil diperoleh gambaran tentang spesifikasi tenaga yang diperlukan.

Pendidikan dan latihan sesuai dengan Pasal 2 Peraturan Pemerintah No. 101 Tahun 2000 tentang Pendidikan dan Pelatihan Jabatan Pegawai Negeri Sipil bertujuan :

a. Meningkatkan pengetahuan, keahlian, ketrampilan, dan sikap untuk dapat melaksanakan tugas jabatan secara profesional dengan dilandasi kepribadian dan etika PNS sesuai dengan kebutuhan instansi.

b. Menciptakan aparatur yang mampu berperan sebagai pembaharu dan perekat persatuan dan kesatuan bangsa.

c. Memantapkan sikap dan semangat pengabdian yang berorientasi pada pelayanan, pengayoman, dan pemberdayaan masyrakat.

d. Menciptakan kesamaan visi dan dinamika pola pikir dalam melaksanakan tugas pemerintahan umum dan pembangunan demi terwujudnya pemerintahan yang baik.

Pendidikan dan latihan (Diklat) dalam jabatan juga sebagai penilaian seperti diatur dalam Pasal 8 Peraturan Pemerintah No. 101 Tahun 2000 yaitu :

(1) Diklat dalam jabatan dilaksanakan untuk mengembangkan pengetahuan, ketrampilan, dan sikap PNS agar dapat melaksanakan tugas tugas pemerintahan dan pembangunan dengan sebaik-baiknya.

(2) Diklat dalam jabatan terdiri dari:

a. Diklat kepemimpinan.

b. Diklat Fungsional.

c. Diklat Teknis.

Diklat yang diatur dalam ketentuan pasal tersebut dipakai sebagai syarat kompetensi aparatur pemerintah yang sesuai dengan jenjang. Adapun di dalam Pendidikan dan Pelatihan pimpinan sesuai Pasal 10 Peraturan Pemerintah No. 101 Tahun 2000 adalah :

a. Diklatpim Tingkat IV adalah Diklatpim untuk Jabatan Struktural Eselon IV. 
b. Diklatpim Tingkat III adalah Diklatpim untuk Jabatan Struktural Eselon III.

c. Diklatpim Tingkat II adalah Diklatpim untuk Jabatan Sruktural Eselon II.

d. Diklatpim Tingkat I adalah Diklatpim untuk Jabatan Struktural Eselon I.

Adapun dalam jabatan fungsional parosedur diatur sesuai Pasal 3 Peraturan Pemerintah No.16 Tahun 1994 tentang Jabatan Fungsional Pegawai Negeri Sipil bahwa jabatan fungsional keahlian dan jabatan fungsional keaterampilan ditetapkan dengan kriteria sebagai berikut :

a. Mempunyai metodologi, teknik analisis, teknik dan prosedur kerja yang didasarkan atas disiplin ilmu pengetahuan dan atau pelatihan teknis tertentu dengan sertifikasi.

b. Memiliki etika parofesi yang ditetapkan oleh organisasi profesi.

c. Dapat disusun dalam satuan jenjang jabatan berdasarkan (1) Tingkat keahlian bagi jabatan fungsional keahlian dan (2) Tingkat ketrampilan bagi jabatan fugsional keterampilan.

d. Pelaksanaan tugas bersifat mandiri.

e. Jabatan fungsi tersebut diperukan dalam pelaksanaan tugas pokok dan fungsi organisasi.

Mutasi jabatan fungsional ke dalam jabatan struktural dalam lingkup organisasi (instansi) aparatur pemerintah daerah tanpa landasan hukum yang kuat akan mempengaruhi kinerja aparatur pemerintah daerah. Dampak tersebut berkaitan dengan persepsi, perilaku dan gaya manajerial yaitu terjadi penyalagunaan wewenang dan jabatan, dapat menjadi alat kepentingan tertentu, terjadi kecenderungan mempertahankan status quo, takut mengambil keputusan, kreatifitas dan kredibilitas rendah, terjadi nepotisme, dan patronase. Karena kurang pengetahuan dan ketrampilan akan menjadi ketidakmampuan menjabarkan kebijaksanaan pimpinan, tindakan yang dilakukan tidak produktif, mutu hasil pekerjaan rendah, melakukan kegiatan yang tidak relevan, dan menyebabkan stagnasi.

Penyelenggaraan dan memelihara manajemen informasi kepegawaian Pejabat Pembina Kepegawaian Daerah wajib menyampaikan setiap jenis 
mutasi kepegawaian kepada Kepala Badan Kepegawaian Negara mengenai pelaksanaan pengangkatan, pemindahan maupun pemberhentian PNS. Suatu persoalan mendasar yang menjadi penyebab adalah belum diperolehnya kesepakatan mengenai variabel dan indikator-indikator yang digunakan. Dalam penilaian kinerja berkaitan dengan proses mutasi jabatan masih belum jelas dalam menentukan indikator sesuai dengan tujuan dan misi pemerintah daerah serta organisasi pemerintah daerah yang multidimensi dan luas. Penilaian pegawai atau aparatur pemerintah merupakan bagian yang penting dalam proses untuk pengangkatan dan pemindahan jabatan struktural. Suatu penilaian membantu pengambilan keputusan untuk promosi pemindahan, pemberhentian dan pemecatan (Dale S Beach dalam Moekijat, 199 :100 ).

Penilaian kinerja dilakukan oleh Badan Pertimbangan Jabatan (Baperjakat) sesuai Pasal 14 Peraturan Pemerintah No. 100 Tahun 2000 Tentang Pengangkatan Pegawai Negeri Sipil dalam jabatan struktural tugasnya hanya memberikan pertimbangan kepada Pejabat Pembina. Selain itu, dalam kenaikan pangkat harus menunjukkan prestasi kerja yang luar biasa baiknya dan menemukan penemuan baru yang bermanfaat bagi negara. Dalam Peraturan Pemerintah yang dijabarkan dalam Baperjakat daerah tidak mengatur ketentuan penilaian kerja secara detail yang berguna untuk mengembangkan standarstandar tertulis uraian jabatan. Perlu ditunjukkan standar-standar pelaksanaan pekerjaan itu adalah relatif bagi organisasi. Tidak hanya kebutuhan-kebutuhan dari masing-masing organisasi itu berlainan, tetapi kecakapan pegawai akan berlainan pada beberapa organisasi atau instansi.

Penggunaan peraturan perundang-undangan pemerintahan daerah dapat mewarnai prosedur dalam pengangkatan dan mutasi jabatan struktural aparatur pemerintah daerah. Kepala Daerah memiliki kewenangan sehingga menentukan dalam menata dan mensukseskan jalannya birokrsi sebagai pelayanan publik. Bahkan tujuan dibentuk Badan Pertimbangan Jabatan dan Kepangkatan yaitu dalam rangka membantu pejabat yang berwenang untuk mewujudkan obyektifitas pengangkatan, pemindahan dan pemberhentian dalam dan dari Jabatan struktural. 
Kewenangan kepala daerah dalam pembuatan kebijakan memiliki kekuatan politik yang dominan dari pada kekuatan hukum yang diimplementasikan lewat produk hukum. Ini mempengaruhi pola pengembangan dan peningkatan sumber daya manusia. Dalam format seperti ini, kebutuhan tersedianya sumber daya manusia yang berkualitas menjadi dasar pertimbangan utama.

Proses mutasi jabatan pada setiap SKPD selalu menggunakan Kantor Badan Kepegawaian Daerah Kabupaten/Walikota setempat. Sehingga apabila ditinjaunya dari aspek persyaratan masih ada kelihatan ada upaya penempatan seseorang sesuai dengan kemauan masing-masing pemimpin kepala daerah. Selain itu, tindakan mutasi hanya untuk menggeser sesorang PNS dari jabatan yang sebelumnya karena telah nyaman melakukan tindakan yang akan dikategorikan keluar dari kepentingan kemauan kepala daerah yang bersangkutan. Oleh karena itu, SKPD yang ditugaskan untuk menyeleksi PNS yang akan dimutasi selalu diperdayakan dengan kepentingan kekuatan atau kemauan kepala daerah bukan untuk menetralisasikan program yang akan dilaksanakan.

Konsekuensi dari tindakan tersebut tentu yang akan terjadi adalah PNS yang tidak memenuhi persyaratan dan kompetensinya juga akan mendapatkan kedudukan. Sementara apabila dilihat dari jenjang pendidikan dan pelatihan yang belum dipenuhi oleh PNS yang akan dimutasi. Selain itu, juga faktor kompetensi pegawai tidak sesuai dengan penempatan jabatan struktural pegawai.

Tindakan kepala daerah dalam melakukan intervensi yang mengarah kepada kepentingan individu, kelompok dan politis hendaknya diminimalisir, dan lebih mengedepankan intervensi profesional sehingga dapat tercipta asas the right man on the right place and on the right job. Pelaksanaan kewenangan kepala daerah dalam penentuan mutasi pegawai negeri sipil dalam jabatan struktural sering digambarkan sejalan dengan meningkatnya kewenangan Kepala Daerah, termasuk bidang manajemen kepegawaian daerah di antaranya 
kewenangan pengangkatan dalam jabatan di lingkungan pemerintah daerah atau yang dikenal dengan mutasi.

Sementara pada sisi lain, secara normatif berdasarkan Pasal 17 ayat (2) Undang-undang Nomor 43 Tahun 1999 tentang Perubahan Undang-Undang Nomor 8 Tahun 1974 tentang Pokok-pokok Kepegawaian, ditegaskan bahwa Pengangkatan Pegawai Negeri Sipil dalam suatu jabatan dilaksanakan berdasarkan prinsip profesionalisme sesuai dengan kompetensi, prestasi kerja, dan jenjang pangkat yang ditetapkan untuk jabatan itu serta syarat obyektif lainnya tanpa membedakan jenis kelamin, suku, agama, ras atau golongan

Berdasarkan hasil temuan penelitian dapat diketahui bahwa pengaturan pengangkatan pegawai negeri sipil dalam jabatan struktural, yang diikuti dengan ketentuan pelaksanaannya masih bersifat normatif, belum menyentuh pada teknis, sehingga pengangkatan PNS dalam jabatan struktural yang dimaksudkan untuk membina karier PNS tidak dapat terlaksana. Lebih lanjut dijelaskan bahwa prinsip Pengangkatan PNS dalam suatu jabatan dilaksanakan dengan beberapa pertimbangan yakni: (1) Profesionalisme sesuai dengan kompetensi; (2) Prestasi kerja, dan (3) Jenjang pangkat yang ditetapkan untuk jabatan itu serta (4) Syarat obyektif lainnya tanpa membedakan jenis kelamin, suku, agama, ras atau golongan. Dalam tataran praktik, prinsip tersebut tidak memiliki ukuran atau instrumen penilaian atau pengujian secara terukur, hal ini dapat dilihat dari: Pertama, Ukuran profesionalisme sesuai dengan kompetensi, tidak berlaku di lingkungan jabatan struktural sepanjang karier pegawai sejak pengangkatan sebagai PNS. Pola profesional sesuai kompetensi dapat terukur bagi Pejabat Fungsional di lingkungan pemerintah daerah seperti tenaga kesehatan dan tenaga pendidikan, melalui ukuran profesi seperti dokter dan guru serta auditor, dengan portofolio dan angka kredit sebagai yang sinkron dengan kepangkatannya. Kedua, Demikian pula dengan ukuran prestasi kerja, satu-satunya pengakuan atau penghargaan yang diberikan pemerintah atas prestasi kerja adalah kesetiaan berdasarkan masa jabatan dengan satya lencana.

Hal inilah yang kemudian menjadi celah hukum bahwa pengangkatan pegawai negeri sipil dalam jabatan struktural, dipersepsikan secara dominan 
dipengaruhi oleh kepentingan politik atau pimpinan daerah yang berproses legal melalui Baperjakat.

Mekanisme pengangkatan, pemindahan dan pemberhentian pegawai negeri sipil dalam dan dari jabatan struktural telah diatur dalam Undang-undang Nomor 43 Tahun 1999, keberadaan undang-undang ini dalam rangka usaha mencapai tujuan nasional untuk mewujudkan masyarakat madani dan taat hukum, berperadaban modern demokratis, makmur, adil dan bermoral tinggi, diperlukan Pegawai Negeri yang merupakan unsur aparatur negara yang bertugas sebagai abdi masyarakat yang menyelenggarakan pelayanan secara adil dan merata, menjaga persatuan dan kesatuan bangsa dengan penuh kesetiaan kepada Pancasila dan Undang-Undang Dasar 1945.

Di era globalisasi yang sarat dengan tantangan, persaingan dan perkembangan ilmu pengetahuan dan teknologi serta untuk mencapai efektifitas dan efisiensi dalam penyelenggaraan tugas pemerintahan, tidak ada alternatif lain kecuali peningkatan kualitas profesionalisme pegawai negeri sipil yang memiliki keunggulan kualitas dan memegang teguh etika birokrasi dalam memberikan pelayanan yang sesuai dengan tingkat kepuasan dan keinginan masyarakat.

Sejalan dengan hal tersebut, untuk menciptakan sosok pegawai negeri sipil sebagaimana dimaksud di atas dipandang perlu menetapkan norma pengangkatan pegawai negeri sipil dalam jabatan struktural secara sistematik dan terukur, mampu menampilkan sosok pejabat struktural yang professional sekaligus berfungsi sebagai pemersatu serta perekat rasa persatuan dan kesatuan bangsa dengan tetap mempererhatikan perkembangan intensitas tuntutan keterbukaan, demokratisasi, perlindungan hak asasi manusia dan lingkungan hidup.

Manajemen pegawai negeri sipil perlu diatur secara menyeluruh, dengan menerapkan norma, standar dan prosedur yang seragam dalam penetapan formasi, pengadaan, pengembangan, penetapan gaji, dan program kesejahteraan, serta pemberhentian yang merupakan unsur dalam manajemen pegawai negeri sipil di seluruh Indonesia. 


\section{Simpulan}

1. Pengaturan mutasi pejabat fungsional untuk menduduki jabatan struktural belum diatur secara khusus dalam ketentuan perundang-undangan, namun dengan berlakunya Undang-undang Nomor 5 Tahun 2014 tentang Aparatur Sipil Negara, maka di daerah mengacu pada Pasal 68 ayat ( 4 ) bahwa PNS dapat berpindah antar dan antara Jabatan Pimpinan Tinggi, Jabatan Administrasi, dan Jabatan Fungsional di Instansi Pusat dan Daerah berdasarkan kualifikasi, kompetensi, dan penilaian kinerja.

2. Prosedur dan mekanisme mutasi pejabat fungsional untuk menduduki jabatan struktural yang dilakukan di daerah adalah melalui Badan Pertimbangan Jabatan dan Kepangkatan atau Baperjakat yang tugasnya memberikan pertimbangan kepada Kepala daerah namun tidak sepenuhnya memperhatikan kulifikasi, kompetensi dan penilaian kinerja PNS sehingga belum terciptanya asas the right man on the right place and on the right job.

\section{E. Saran}

1. Pengaturan mutasi pejabat fungsional untuk menduduki jabatan struktural di daerah belum ada maka Kepala daerah melalui Baperjakat perlu memperhatikan kulaifikasi, kompetensi dan pola penilaian kinerja PNS sehingga tidak salah memutasikan pejabat fungsional yang akan menduduki jabatan struktural.

2. Prosedur mutasi pejabat fungsional untuk menduduki jabatan struktural di daerah, Baperjakat harus memperhatikan 2 hal yaitu :

a. Analisis tugas jabatan (job analisys) yang baik, suatu analisis yang menggambarkan tentang ruang lingkup dan sifat-sifat tugas yang dilaksanakan sesuatu unit organisasi dan syarat-syarat yang harus dimiliki oleh pejabat yang akan menduduki jabatan di dalam unit organisasi itu.

3. Penilaian Pelaksanaan Pekerjaan (kecakapan pegawai) dari masingmasing pegawai yang terpelihara dengan baik dan terus-menerus. Dengan adanya penilaian pekerjaan ini dapat diketahui tentang sifat, kecakapan, disiplin, prestasi kerja, dan lain-lain dari pejabat tersebut. 


\section{DAFTAR PUSTAKA}

Alex. S. Nitisemito. 1996. Manajemen Personalia. Jakarta :Ghalia Indonesia.

A.W. Wijaya. 1986. Administrasi Kepegawaian Suatu Pengantar. Jakarta : Penerbit CV. Rajawali.

Philipus M. Hadjon. 1994. Fungsi Normatif Hukum Administrasi dalam Mewujudkan Pemerintahan yang Bersih, Pidato Pada Peresmian Penerimaan Jabatan Guru Besar Dalam Ilmu Hukum Pada Fakultas Hukum Universitas Airlangga, Surabaya.

Makatutu dan Pangkerego. 1975. Teori Suatu Hukum Tata Negara Positif. Jakarta : Ikhtiar Baru-Van Hoeve.

Moekijat. 199l. Administrasi Kepegawaian Negara. Cetakan l. Bandung : Mandar Maju.

Pudja Pramana KA. 2009. Ilmu Negara. Jogjakarta : Maju Mondar.

Poerwasunata, W.J.S. 2003. Kamus Bahasa Indonesia edisi ketiga. Jakarta : Balai Pustaka.

Sondang P. Siagian. 1992. Kerangka Dasar Dalam Administrasi. Jakarta : Rineka Cipta.

SP. M. Hasibuan. 1994. Manajemen Sumber Daya Manusia. Jakarta : CV. Haji Mas Agung.

Sri Hartini, dkk. 2010. Hukum Kepegawaian di Indonesia. Jakarta. Penerbit Liberty.

Utrecht, E. 1960. Pengantar Hukum Administrasi Negara Indonesia. Cetakan 4, Bandung : Fakultas Hukum Universitas Padjajaran.

Bilson Simamora. 2005. Analisis Multivariat Pemasaran. Jakarta : PT. Gramedia Pustaka Utama.

\section{Peraturan Perundang-undangan}

Undang-undang Dasar Negara Republik Indonesia Tahun 1945

Undang-Undang Nomor 43 Tahun 1999 tentang Perubahan Atas Undang-Undang Nomor 8 Tahun 1974 tentang Pokok-Pokok Kepegawaian, LNRI Tahun 1999 Nomor 169, TLNRI Nomor 3890.

Undang-undang Nomor 5 Tahun 2014 tentang Aparatur Sipil Negara, Lembaran Negara Republik Indonesia Tahun 2014 Nomor 6, Tambahan Lembaran Negara Republik Indonesia Tahun 2014 Nomor 5494.

Undang-Undang Republik Indonesia Nomor 23 Tahun 2014 tentang Pemerintahan Daerah, LNRI Tahun 2014 Nomor 244 dan TLNRI No 5587

Peraturan Pemerintah RI Nomor 100 Tahun 2000 tentang Pengangkatan Pegawai Negeri Sipil dalam Jabatan Struktural.

Peraturan Pemerintah Nomor 13 Tahun 2002 tentang Pengangkatan Pegawai Negeri Sipil Dalam Jabatan Struktural, Lembaran Negara Republik Indonesia Tahun 2002 Nomor 33, Tambahan Lembaran Negara Republik Indonesia Tahun 2002 Nomor 4194. 